\title{
退院後の暮らしを見据えた病院看護職育成のための現状 と課題：病院管理者等へのグループインタビューから
}

Circumstances and Challenges in Home Care-oriented Hospital Nurse Training: Using Group Interviews for Nurses Who Engage in Hospital Nursing Administration

\section{牛久保美津子＼cjkstart近藤 浩子＼cjkstart塚 越 徳子＼cjkstart菊 地 沙 織 上山 真 美 恩幣 宏 美 堀越政孝 常盤洋子}

Mitsuko Ushikubo, Hiroko Kondo, Noriko Tsukagoshi, Saori Kikuchi, Manami Kamiyama, Hiromi Onbe, Masataka Horikoshi, Yoko Tokiwa

\begin{abstract}
要 旨
目的：病院看護職による退院後の暮らしを見据えた看護活動の自己評価の結果をもとに, 在宅ケアの視点をも つ病院看護職育成のための課題を明確化すること.

方法：9病院，13名の看護師を対象にしたグループインタビューを行い，質的州納的に分析した.

結果・考察：退院後の暮らしを見据えた看護活動の現状として，6カテゴリ：《他職種にまかせきりにしてい る》, 《院内連携ができていない》, 《訪問看護師との連携には格差がある》, 《社会資源の知識がなく活用ができ ていない》, 《勉強会参加, 経験年数, 興味関心により在宅ケアの視点をもつことができる》, 《在宅ケアの知識 があっても実践力がない》が抽出された，社会資源に関する知識不足や多職種連携ができてないことから, 実 践に結び付いていないことが考えられた.

結論：退院後の暮らしを見据えた看護職育成の課題として, 社会資源に関する実践的な知識不足を補うこと, かつ他分野他部署を超えた看護経験の積み重ねができるような勤務体制・施設間交流の工夫を行うなど, 会得 した知識を実践へと結び付けるための個人の資質向上と組織的な教育的取り組みが必要であることが示唆され た.
\end{abstract}

\begin{abstract}
Objective: This study aimed to clarify the circumstances and challenges in home care-oriented hospital nurse training on the basis of results of hospital nurse self-evaluations of nursing activities implemented in preparation for home care.

Methods: Group interviews were conducted with 13 nurses at 9 different hospitals, and the results were qualitatively and inductively analyzed.

Results and Discussion: Six categories for actual nursing activities implemented in preparation for home care were extracted. These categories were "I leave home care to other medical professionals," "No form of inter-hospital cooperation has been established," "There is disparity in cooperation with home-visiting nurses," "Social resources are not being used due to a lack of knowledge," "Able to develop a perspective of home care through workshop participation, years of experience, and interest," and "Competency is lacking despite knowledge of home care." Home care was apparently not being utilized by hospital nurses due to a lack of knowledge of social resources and a lack of interdisciplinary cooperation.

Conclusions: Challenges in nurse training implemented in preparation for home care included compensating for the lack of practical knowledge of social resources and devising a duty system and inter-facility exchanges to allow nurses to build experience in other areas and departments. The results of this study suggested the need
\end{abstract}

群馬大学大学院保健学研究科

著者連絡先 : 牛久保美津子 群馬大学大学院保健学研究科看護学講座 [下371-8514 群馬県前橋市昭和町 3-39-22]

email: ushi2@gunma-u.ac.jp

（受付日：2016 年 8 月 18 日, 採用日：2016 年 11 月 15 日）

(C)2017 日本プライマリ・ケア連合学会 
for organizational training initiatives and for improvement of the quality of individuals in order to put acquired knowledge into practice.

Keywords : 在宅 (Home care), 病院看護師（Hospital nurse）, 退院支援（Discharge support）, 現任教育 (Recurrent training)

\section{はじめに}

我が国の医療は, 急性期医療を中心に発展してきた ため, 医学, 薬学, 歯科学, 看護学等の教育において は病院中心の人材養成が主とされてきた。しかし, 病 院医療から地域 - 在宅医療へのシフトや, 超高齢社会 に対応するためには, 地域包括ケアシステムで役割機 能を発揮できる医療人材の養成が喫緊の課題であ $る^{1.2)}$.

看護基礎教育では, 1996 年のカリキュラム改正によ り, 在宅看護論・在宅看護実習が正式に科目として位 置づけられ, 約 20 年が経過した. 病院では機能分化・ 再編がさらに進められ, 在宅退院率の目標数值が設定 された，人々のクオリティ・オブ・ライフの維持向上 や病院経営の安定化をはじめ, 必要なときに必要な場 所で必要な医療やケアを受けられる適正入院の考え方 のもと, 病院看護師には, 患者の次の療養場所への久 ムーズな移行を支援し, 切れ目のない医療や看護のた めの役割，すなわち地域完結型の看護実践がもとめら れている.

そのため, 本研究者らは, 2014 年度に, 群馬県内 11 病院の看護師を対象に「在宅を見据えた看護活動の自 己評価」の調査 ${ }^{3}$ をし, 現状把握を行った。本研究は, その結果をもとにして, 調查対象施設の代表者から広 く意見を聴取し, 退院後の暮らしを見据えた看護がで きる病院看護職育成のための現任教育の課題を明らか にすることを目的とした。

\section{方 法}

\section{1. 研究デザイン}

質的記述的研究

\section{2. 対象と方法}

対象者は, 参加同意の得られた群馬県内 9 病院, 13 名の看護師 (部長, 師長, 退院支援担当者）で, 調查 方法はグループインタビュー法とし， 3 グループに分 け, インタビューガイドを用いて 90 分間のインタ ビューを行った．各グループには，打ち合わせを行っ たファシリテーターを抄き，グループ間で統一したイ ンタビュー方法で実施できるようにした，グループイ ンタビュー法を用いた理由は, 各参加者が他病院の参
加者と交流することで, 自施設の特徴をふまえて課題 をより気づきやすくなるよう，共同想起の利点がある からである。

参加者には, 2014 年度に実施した「在宅を見据えた 看護活動の自己評価 (25 項目)」の結果を, 11 施設全 体 (2,136 名) の集計グラフおよび当該施設の集計グラ フにして配布した。これを見ながら評価項目ごとの実 施率の差, 実施率と看護師の属性の関係, 実施率を改 善するための提案について意見を自由に出してもらっ た、インタビュー内容は，ICレコーダーに録音した。

なお, 2014 年度の調查研究における対象病院は, 群 馬県内全域を網羅するように選定した. 病院の規模は, 3 施設が 100 300 床, 6 施設が 300 床台, 2 施設が 500 床以上であった. 調查対象者の年齢は 30 歳未満, 30 歳代, 40 歳以上がそれぞれ約 3 割で, 経験年数は 5 年未満, $5 \sim 10$ 年, 10 年以上がそれぞれ約 3 割, 2 割, 5 割であった. 職種は看護師が 9 割で, 在宅看護論・実 習の履修者が 7 割, 訪問看護・在宅ケアに関する研修 の受講者が 3 割, また退院支援に関する研修受講希望 者が 7 割であった，看護学生の実習指導に関わってい る者が 2 割いた

\section{3. 分析方法}

Berelson.B の内容分析の手法 ${ }^{4}$ を参考に, 以下の手順 で行った。まず，グループ毎のインタビュー内容を逐 語録に起こし精読した. 次に, 退院後の暮らしを見据 えた看護実践に関する病院看護職の現状と課題が語ら れた文脈を意味内容に沿って抽出し記録単位とした。 記録単位を集め, 意味内容を変えない一文に表現する 作業を行い，これをコードとした．全グループのコー ドを集め, 意味内容の類似性に従ってサブカテゴリを 抽出し，さらにカテゴリを抽出した．

\section{4. 真実性の確保}

コードの解釈, カテゴリ分類の妥当性について, 共 同研究者間による検討を行い, 分析の真実性確保に努 めた，研究者間で判断が困難である場合には，繰り返 し討議し, 検討を重ねた上で決定した. 質的研究に精 通する看護学研究者 3 名からスーパーバイズを受け た. 
表 1 病院看護職における退院後の暮らしを見据えた看護実践の現状

\begin{tabular}{|c|c|}
\hline カテゴリ & サブカテゴリ \\
\hline 他職種にまかせきりにしている & $\begin{array}{l}\text { ·多職種との意見交換に若手看護師が発言できない } \\
\text { ·病棟看護師は在宅移行支援を他職種に依頼したら, 任せきりにしている } \\
\text { •病棟看護師は多職種に対して看護職としての意見が言えない } \\
\text { •薬剤に関する調整は専門職である薬剤師に依頼している } \\
\text { ·在宅移行支援は医師の考えに影響する }\end{array}$ \\
\hline 院内連携ができていない & $\begin{array}{l}\text { •病棟看護師は地域連携室との連携ができていない } \\
\text { •病棟看護師と外来看護師の連携が難しい }\end{array}$ \\
\hline 訪問看護師との連携には格差がある & $\begin{array}{l}\text { ·訪問看護との連携を工夫して情報活用を意識的に行う } \\
\text { •病棟看護師は訪問看護の情報活用ができていない }\end{array}$ \\
\hline 社会資源の知識がなく活用できていない & $\begin{array}{l}\text { ・病棟看護師は社会資源活用についての関心が薄い } \\
\text { ・病棟看護師は社会資源活用を主体的に行っていない } \\
\text { ・社会資源活用は看護師の経験値に影響する } \\
\text { ・病棟看護師は社会資源を活用するための知識がない } \\
\text { ・病棟看護師は障害認定見込みについて知らない }\end{array}$ \\
\hline $\begin{array}{l}\text { 勉強会参加, 経験年数, 興味関心により } \\
\text { 在宅ケアの視点を持つことができる }\end{array}$ & $\begin{array}{l}\text { ・意識の高い看護師は在宅ヶアの視点を持つ看護ができる } \\
\text { ・経験年数が高いと在宅ケアの視点を持った看護ができる } \\
\text { •多くの部署の経験によって在宅ケアの視点をを持った看護ができる } \\
\text { •在宅看護論の履修は在宅ケアの視点を持った看護に結びつく }\end{array}$ \\
\hline 在宅ケアの知識があっても実践力がない & $\begin{array}{l}\text { ・病棟看護師は患者の退院後の生活にまで考えが及ばない } \\
\text { ・急性期病院なので在宅移行支援ができない } \\
\text { ·在宅ケアの勉強会や研修会の効果が出ていない } \\
\text { ·病棟看護師は在宅ケアの知識はあっても実践力がない }\end{array}$ \\
\hline
\end{tabular}

\section{5. 倫理的配慮}

著者の所属大学の医学部疫学倫理審査委員会の承認 を得た（承認番号 27-22）.

\section{結果（表 1）}

退院後の暮らしを見据えた看護活動の現状として, 162 記録単位, 119 コード, 22 サブカテゴリから 6 カテ ゴリが抽出された. 以下, カテゴリは《》で, サブ カテゴリはく >, コードは“”で示す。また,【】 内にカテゴリの記録単位数とその比率を示す.

\section{1.《他職種にまかせきりにしている》(記録単位数} 31 個, 19\%】

このカテゴリは，5 サブカテゴリから構成された. “他職種に頼んだら頼みっぱなしで, 他職種が重なりな がらチームにならないと寄せ集めのような気がする” や“看護師は他職種に連絡するのみでお任せしてしま うため, それを連携とは言えない”など, <病棟看護 師は在宅移行支援を他職種に依頼したら，任せきりに している>が挙げられた. また, “カンファレンスでは, 病棟のトップやベテランを中心に意見交換をしてしま い，若い子が発言する機会が少ないため，他職種との 意見交換の実施率が低い”など，＜多職種との意見交 換に若手看護師が発言できない>が挙げられ，若手看 護師の多職種連携における課題を感じていた。“看護師
が他職種と意見交換する上で，患者の生活を看るとい う視点が欠けていると意見交換に至らない”ゃ“看護 師が他職種に意見が言えない理由として，経験と知識 不足が考えられる”など，〈病棟看護師は他職種に対 して看護職としての意見が言えない>も挙げられた。

\section{2.《院内連携ができていない》【記録単位数 15 個,} 9\%】

このカテゴリは, 2 サブカテゴリから構成され, 最も 少ない記録単位数であった。“師長やリーダー看護師が 退院の話などを地域連携室につなぎ, 病棟看護師は地 域連携室と直接に相談することは少ないので関わりが 薄い”などく病棟看護師は地域連携室との連携ができ ていない>が挙げられた，地域連携室だけでなく，“患 者の在宅での生活について病棟看護師と外来看護師で の引継ぎが難しい”など，<病棟看護師と外来看護師 の連携が難しい>も挙げられ，院内連携を不十分に感 じていた.

\section{3.《訪問看護との連携には格差がある》(記録単位 数 17 個, $11 \%$}

このカテゴリは, 2 サブカテゴリから構成された. 自 施設に訪問看護ステーションが設置されている対象者 からは, “訪問看護師に意識的に働きかけ，患者の入院 前や退院後の生活について話しながらやっているの で，訪問看護からの情報活用の実施率が高い”など, 
く訪問看護との連携を工夫して情報活用を意識的に行 う>が挙げられた。一方で, “地域の訪問看護ステー ションが遠方であるため, 訪問看護からの情報活用の 実施率が低い”や“病院スタッフが訪問看護の力を把 握できていない現実がある”など，＜病棟看護師は訪 問看護の情報活用ができていない>も挙げられた.

\section{4. 《社会資源の知識がなく活用ができていない》 【記録単位数 34 個, 21\%】}

このカテゴリは，5サブカテゴリから構成され， 2 番目に多い記録単位数であった. “病棟スタッフが地域 の社会資源などをあまり知らず，関心が薄い”など， ＜病棟看護師は社会資源活用についての関心が薄い＞ が挙げられた。同様に, <病棟看護師は障害認定見込 みについて知らない>, <病棟看護師は社会資源を活 用するための知識がない>, “生活保護や転院など社会 資源が必要な患者は MSW（メディカルソーシャル ワーカー）に依頼するので, 看護師自身の社会資源に ついての知識は低い”など, <病棟看護師は社会資源 活用を主体的に行っていない>が挙げられ, 看護師の 社会資源活用に関する知識や主体性の不足を感じてい た.また, “社会資源の活用は看護管理職が行うことが 多いため, 経験值が影響している”など, <社会資源 活用は看護師の経験値に影響する>も挙げられた。

\section{5. 《勉強会参加, 経験年数, 興味関心により在宅ヶ アの視点を持つことができる》【記録単位数 23} 個, 14\%】

このカテゴリは, 4 サブカテゴリから構成された. 退 院後の暮らしを見据えることができている看護師の特 徵について語られた、“経験年数が多いスタッフがいる ので, 生活者として患者・家族を看る視点ができてい る”など，＜経験年数が高いと在宅ケアの視点を持っ た看護ができる>が挙げられた. 同様に, “回復期病棟 と急性期病棟, 両方の勤務経験があるスタッフは患者 が在宅でどのように過ごすのかを考えて視野を広げら れる”など，＜多くの部署の経験によって在宅ケアの 視点を持った看護ができる>や“在宅看護論を履修し て看護師になった人は, 地域連携を経験することで在 宅に向けた看護に結び付けられている”など，＜在宅 看護論の履修は在宅ケアの視点を持った看護に結びっ く〉も挙げられた。一方で, “在宅看護論を履修してい なくても, 在宅看護に興味関心がある看護師は, 在宅 ケアの視点を持って看護ができる”や“看護師が「こ ういう風な形で患者さんを帰したい」と思うと，いろ んなことができる”など, ＜意識の高い看護師は在宅 ケアの視点を持つ看護ができる>も挙げられ, 経験年
数や部署, 教育に関係なく, 在宅への意識の違いによっ て看護実践が影響することも感じていた。

\section{6. 《在宅ケアの知識があっても実践力がない》【記 録単位数 42 個, 26\%]}

このカテゴリは, 4 サブカテゴリから構成され, 最も 多い記録単位数であった. “入院中の患者をみて, どの ような家に住んでいるのか, 自宅に帰ったらどうなる のかイメージが持てないので, 病院での看護しかでき ない”など，＜病棟看護師は患者の退院後の生活にま で考学が及ばない>が挙げられた。 “退院支援や訪問看 護の研修をしているが, 実際に病棟で実施しないので, 興味がなくギャップが大きい”や“師長を対象とした 退院支援研修を行っても, 身になっているか, 変化が あるのか実感がない”など，＜在宅ケアの勉強会や研 修会の効果が出ていない>が挙げられた. また, “大学 で在宅支援の教育を受けていても学んだことが活かせ ないのは, 若手看護師の余裕がなく, 在宅視点の看護 よりも目先の業務に必死なためだ”など，＜病棟看護 師は在宅ケアの知識はあっても実践力がない>が挙げ られ, 例え知識を得たとしても, 実践に移す力が不足 していると感じていた，他に，＜急性期病院なので在 宅移行支援ができない>があげられた.

加えて, 若手看護師に焦点をあてて分析した結果 を示す.《在宅ケアの知識があっても実践力がない》, く病棟看護師は在宅ケアの知識はあっても実践力がな い>のコード 10 個のうち, 7 個は若手看護師（1３ 年目）に関する内容であった，若手看護師は, 在宅看 護論を履修し在宅視点の知識はあるものの, 実践力不 足が課題であると認識していた.また，《他職種にまか せきりにしている》の<多職種との意見交換に若手看 護師が発言できない>では，若手看護師が発言できる 経験が少ないことを問題視していた. しかし, 《勉強会 の参加や経験年数により在宅ケアの視点を持つことが できる》では,「経験 (年数や多くの部署)によって在 宅視点を持つことができる」ということが示された。 これらから, 在宅看護論を履修している若手看護師は 知識があっても実践力がないが, 経験によって退院後 の暮らしを見据えた看護へ結びついている看護師もい ることが明らかとなった。

\section{考 察}

2014 年に害施した調査では, 入院中のケアに直結す る看護活動, すなわち患者の入院前の生活状況の把握, 患者や家族の希望の把握, およびサマリー記載の実施 率は 5 割以上と比較的よく実施されていた。一方で, 
退院後の暮らしを見据えた看護, すなわち居住環境の 把握や社会資源の把握, 介護認定や障害認定の見込久 の評価, ケア方法の簡素化, 今後を予測した対応, 多 職種との連携については実施率が 4 割以下であまり実 施されていなかっだ3. 今回のインタビューの目的は, このような調查結果が得られた理由を探求するととも に, 退院後の暮らしを見据えた看護が出来る病院看護 職育成の課題を明らかにすることであった.

各病院の地域連携に関する部署あるいは管理職の立 場にいるベテラン看護師へのグループインタビューに より, 在宅ケアの視点をもった看護実践の現状や課題 についての質的デー夕を収集し, 内容分析した結果, 6 カテゴリが抽出された. そのうち, 3 つは多職種連携 に関することであった。 また, 在宅看護に関する勉強 会に参加し知識や在宅ケアの視点の重要性を認識した としても，実践に結びついていないことが明らかに なった.この結果は齋藤等の研究) と同様である. 以上 より, 多職種連携ができていないことや社会資源の活 用の知識不足とあいまって, 実践に結び付いていない ことが考えられた，これらより, 病院看護師が在宅の 視点をもった看護実践ができるための現任教育の課題 を以下に考察した。

1 つは, 他分野他職種を理解できるための現場研修 についてである。退院にあたっては，院内チームから 在宅療養支援チームへとつなぐことが大事であるた め, 地域に扔ける多職種連携はもちろんのこと, 院内 連携は重要である ${ }^{6}$. 院内連携は, 病院の規模が大きい ほど他部署との連携をはかることは難しい。日々の業 務の中で, 他職種の役割を尊重し, かつ他職種にまか せきりにせず協働するというスタンスが重要である。 そのためには, 事例検討会や研修においては他職種を 交えた形で開催することや, 病棟勤務者が地域連携室 や訪問看護ステーション勤務への配置換えや研修を行 うなど，さまざまなところで看護の積み重ねができる よう工夫をする必要がある ${ }^{7 \sim 9)}$.

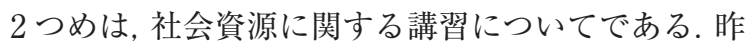
今の医療保健福祉に関する制度の変化はめまぐるし い. 介護保険は 3 年に一度の改正, 医療保険の診療報 酬改定は 2 年に 1 度である。地域には, 年々, 開設す る介護保険サービス事業所の増加やサービス内容・規 模の拡張がある。退院にあたり患者のケアを地域の サービスにつなぐためには, 利用可能なサービスにつ いての情報が必要である。そのためには, 病院看護師 が一般的な社会資源に関する知識や動向を効率よく学 べるための講習会が必要であるとともに，事例ごとの
支援を通して，MSW やケアマネジャーから実践的な 情報を増やす機会が必要である.

3 つめは, 患者の退院後の療養場所に打ける生活状 況を把握することについてである，研修や勉強会など で得た在宅ケアに関する知識を実践に結びつけること の方策を検討する必要がある. 訪問看護同行実習は病 院看護師が退院支援を行ううえで効果的であるとの報 告 ${ }^{7}$ がある. 平成 28 年度の診療報酬改定では, 退院直 後の在宅療養支援に関する評価として, 退院後訪問指 導料や訪問看護同行加算として点数化された ${ }^{10)}$. 入院 中に関わった患者の退院後の生活状況を把握すること が, スタッフ教育という形ではなく, 看護業務として 位置づけられ，ますます病院看護が地域の生活に歩み 寄れる. 加えて, 訪問看護師やケアマネジャーが退院 後の生活状況を病院に報告するなど, 病院と地域が切 れ目なくつながるよう, 院内・地域ぐるみによる取り 組みが必要と考える。

\section{研究の限界と課題}

本調査で見出された課題に対しては，各病院がそれ ぞれの地域性や組織体制をふまえて議論を重ねて具体 策を見出し, 介入研究へとさらに発展させていく必要 がある。

\section{謝 辞}

調査にご協力をいただきました看護師の皆様に感謝 申し上げます。本研究は, 文部科学省補助金 課題解 決型高度医療人材養成プログラム【群馬一丸で育てる 地域完結型看護リーダー】事業として実施しました。

\section{利益相反}

本研究における利益相反はありません。

\section{文 献}

1）石橋みゆき，市村尚子．地域で活躍できる看護人材育成の グッドプラクテイスを支援する 文部科学省「課題解決 型高度医療人材養成プログラム事業」。訪問介護と看護. $2014 ； 19$ (9) : 730-733.

2）石田千絵. 地域・在宅志向のための医療介護関係者の人 材育成教育の動向 (第 1 回) 地域・在宅志向のための基礎 看護教育。保健の科学. $2016 ； 58$ (1)：43-49.

3）近藤浩子, 牛久保美津子, 吉田亨, 他. 群馬県内病院看護 職の在宅を見据えた看護活動に関する実態調查. KMJ. $2016 ; 66: 31-35$.

4）舟島なを久. 質的研究への挑戦第 2 版. 東京: 医学書 院；2007. 40-79.

5）齋藤郁子, 赤間明子, 大竹まり子, 他. 全国の病棟看護師 に㧍ける在宅看護の視点に関する意識ならびに実践の認 
識と関連要因に関する研究. 北日本看護学会誌. $2010 ； 12$ (2) : 13-25

6）宇都宮宏子. 病院から地域への療養移行期の看護マネジ メントを体系化する 地域包括ケアの推進に向けた現状 と課題.看護管理. $2013 ； 23$ （12）：986-995.

7）松原みゆき, 森山薫. 訪問看護の同行訪問を経験した病棟 看護師の退院支援に対する認識の変化. 日本赤十字広島 看護大学紀要. $2015 ； 15: 11-19$.

8）後藤たみ, 林敏美, 田中圭子, 他. 退院支援に関する院内 教育の取り組み 退院支援看護師とのシャドーイングを
試みて. 全国自治体病院協議会雑誌. $2015 ； 54$ (6)：936939.

9）柳井田恭子, 高橋明美, 綱嶋たかえ, 他. 地域連携強化を めざしたポジションチェンジ型研修の実施とその成果 訪問看護ステーションでの 1 日体験型研修をとおして. 川崎市立看護短期大学紀要. $2016 ； 21$ (1) : 59-66.

10）厚生労働省. 平成 28 年度診療報酬改定. 東京: 厚生労働 省 ; [cited 2 August 2016] http://www.mhlw.go.jp/file/0 6-Seisakujouhou.../0000115980.pdf 